\title{
Spreading one's Wings, Milestones, Deus ex Machina: Self-creation as a Process of Changing Your Life with the Examples of Narrations Provided by Women
}

\author{
Aleksandra Chmielińska, and Monika Modrzejewska-Świgulska
}

\author{
University of Lodz, Poland
}

\begin{abstract}
This paper presents narrative-biographic research conducted with participation of women who declare that they have introduced important changes into their lives. The qualitative data was collected using narrative interviews as well as a tool to examine changes in the biographic perspective; namely, Line of life. In the presented paper, the authors reconstructed biographical self-creation, meaning the ways of life in which important changes are a central category of a story about life. The authors reconstruct three different ways of narra-
\end{abstract}

tors' lives - "spreading one's wings," "milestones," "deus ex machina," and a case study that describes the process of self-creation and introduction of important changes into a life in more detail.

\section{KEYWORDS:}

narrative-biographic research, life changes, women, manners of self-creation

\section{Article history:}

Received: January 29, 2020

Received in revised from: May 5, 2021

Accepted: June 11, 2021

ISSN 2354-0036

DOI: $10.2478 /$ ctra-2021-0018

\section{Corresponding author at:}

Aleksandra Chmielińska E-MAIL: aleksandra.chmielinska@uni.lodz.pl

Monika Modrzejewska-Świgulska E-MAlL: monika.modrzejewska@uni.lodz.pl 


\section{INTRODUCTION}

Some time ago, in a Polish women's journal, we found an article describing a dozen or so women who had introduced important changes into their lives, with a particular emphasis on professional changes. The main characters of the reportage were described as women who "have invented their own life," "follow their own way of life," or "have made decisions which changed their lives." We became interested in what was really hidden behind those changes; what those women experienced, what they mean when they speak about a change in their lives, including a professional change, and what the stories of their lives are. We managed to reach some of them; then, we expanded the research group, which we describe in the methodological part of this work. We decided to use the narrative-biographic approach, which provides the narrators with an opportunity of free expression. In addition, qualitative data enabled us to reach our research goal: to reconstruct ways of life including important life changes. Results of the interviews include three different biography types (described by us as manners of the self-creation of one's way of life) and the model of introducing life changes/the model of life re-definitions, as described elsewhere ${ }^{2}$. Below, we present three types of biographical self-creation (biography type) reconstructed by us described as "spreading one's wings," "milestones," and "deus ex machina," with a selected case study that describes in more detail the self-creation process of one of the narrators ${ }^{3}$.

It should not be surprising that a life change has become a central category of the article about women referred to above. The issue of life changes fits into the analysis of processes taking place in the modern world, ${ }^{4}$ where the need to react flexibly to the dynamically changing reality is underlined. In descriptions of the modern society, voices can be heard that notice its advantages and those emphasizing hazards related to life in the modern world. The development and self-creation potential of a modern individual is emphasized; one related to the need of expression, self-fulfilment, and subjectivization of one's actions (Kubiak, 2005; Sennett, 2010; Sztompka, 2010). Experiencing oneself in the "culture of individualism," as it is called by Jacyno (2007), takes place through changing one's own life and taking responsibility for development, success, and happiness 5 . Nowadays, the world provides many opportunities for development and transformation; a modern individual may make choices with regard to their spouse, place of living, course of study, profession, or lifestyle, according to their own preferences or values. What becomes a desired property is an ability of self-understanding and a readiness to introduce life changes favoring development. On the other hand, the modern society is portrayed as too consumerist, atomized, lost in the chaos of possibilities and possible choices, superficial in its opinions, and aspiring to easy, light, and "fluid"

1 In the article, all narrators' statements are written in italics. These statements are taken directly from the article from a Polish women's magazine. We do not provide bibliography to keep the interviewees anonymous.

2 Chmielińska, and Modrzejewska-Świgulska, (2020a, 2020b).

3 A broader description of the research can be found in Chmielińska and Modrzejewska-Świgulska (2020a, b)

4 "Late modern society," "developed society," as proposed by Giddens (2007), or post-modernistic society in postmodernistic approaches.

5 Responses to that include theoretic and practical approaches of positive psychology; namely, a science of happiness and human well-being, which are dynamically developed. 
life. The decisions which are made have nothing in common with autonomic decisions based on self-cognition; they are steered only by the market, fashion, and media (Fukuyama, 2000; Bauman, 2009; Sennett, 2010).

\section{Self-creation as a Process of Forming Oneself: Is it Only Positive?}

One of the expressions used in creative pedagogy as well as development and life course psychology for describing the process of forming oneself and one's own biography/way of life, directing one's own life, self-development, improvement in selected areas (professional, hobby-related, or spiritual ones), and introduction of well-though-out life changes, is self-creation (Całek, 2019; Pawlak, 2009; Pietrasiński, 2008; Schulz, 1990; Szmidt, 2013; Uszyńska-Jarmoc, 2007; Wąsiński, 2018). ${ }^{6}$ In the English-language literature, expressions with similar meaning include self-actualization, introduced by humanist psychologists (Davis, 1999), and everyday creativity, used in modern theories and research in the area of egalitarian approach to creativity. Several theoretic-research tendencies may be distinguished in research on everyday creativity:

- $\quad$ everyday creativity and health. this approach emphasizes positive effects of creative activity on recovery processes (Richards, Kinney, Lunde, Benet \& Merzel, 1997; Richards, 1990, 1997, 2007, 2010; Richards \& Kinney, 1997);

- everyday creativity and processes of gaining knowledge; here, everyday creativity is examined in the context of cognitive processes, such as thinking, making decisions, valorization of one's own creative activity, learning, or gaining language skills (Swann \& Maybin 2007; Runco, 1996, 2006, 2007);

- $\quad$ everyday creativity and solving everyday problems, forming one's own life; the authors of those approaches treat everyday creativity as a natural predisposition to solve problems, seek original and useful solutions, and implement them or, in a wider meaning, as a life attitude showing a deep interest in a surrounding world and multi-aspect perception of reality (Craft, 2000, 2001, 2002; Elisondo \& Vargas 2019; Pachucki, Lena \& Tepper, 2010; Modrzejewska-Świgulska, 2014; Sawyer, 2006; Tan \& Lai-Chong, 2004);

- $\quad$ everyday creativity considered in the context of spiritual development (Arons, 2007).

Self-creation has many meanings and is difficult to define, as Wąsiński (2018) emphasizes. The author referred to above analyzed the understanding of self-creation and distinguished three main theoretic-research approaches in Polish literature (Wąsiński, 2018): (1) philosophical approach - selfcreation is perceived as a process of creating and realizing oneself/aspiring at self-fulfilment; (2)

6 The notion of self-creation also appears in texts written by literary scholars. Całek (2019) forms an interesting concept of self-creation in the context of an epistolary dialogue and proposes four dimensions of self-creation related to the sender of a letter; namely, the biographic dimension (including real "me" and ideal "me"), the cultural dimension (referring to the horizon of meaning shared with the recipient of the letter), and the dimension related to self-creation (a possible "me," conceptualization of oneself). We refer to that concept as it seems interesting and heuristic (i.e. possible to apply) in analyses of not only ready texts (letters) but also those written for the purposes of biographic research (i.e. transcriptions of free and narrative interviews). 
psychological approach - here, self-creation is equated with a creative (active) attitude to life, creative thinking and action, and development of one's personality. the authors recognize self-creation as a whole-life process of developing one's own personality and directing the course of one's own life; they describe it as self-formation, creating one's own way of life, or self-fulfilment. That tendency is developed by both pedagogists and psychologists (Pawlak, 2009; Pietrasiński, 2008; Schulz, 1990; Szmidt, 2013, Uszyńska-Jarmoc, 2007); (3) pedagogical approach - here, self-creation is understood in three manners; as a process of self-education, learning from one's own biography and forming it consciously, and the process of development of ethical awareness (involving oneself in doing good, realizing spiritual values; see Dubas, 2017; Lalak, 2010; Wąsiński, 2018).

To sum up, the wide meaning of "self-creation" should be associated with creating oneself, coforming oneself, or forming one's own biography by actualizing one's own potential; the narrow meaning, on the other hand, should be associated with the aspect of creative activity related to self-education processes.

We describe our understanding of self-creation as a psychological-pedagogical approach, which combines the perspective of development and creative thinking with the pedagogical perspective related to experiencing one's own biography consciously. In the literature, processes of self-creation are usually given a positive meaning and are associated with an ability to influence and the awareness of realized life tasks. However, based on our observations, research, and the literature (ref. to the concept of self-creation by Pietrasiński (2008), we want to ask a perverse question: does self-creation in the long term always have to lead to changes friendly to relationships or health and beneficial for the acting subject?

We agree that self-creation means intentional and deliberate action aimed at forming one's own biography which, in practice, is related to introducing changes (trying new solutions) based on self-cognition ${ }^{7}$ (self-understanding). What is particularly important in the self-creation processes is attempts at self-understanding; in other words, the insight in one's own needs, motivations, and emotions. Situations of confrontation, during which we tell stories or episodes of our lives (i.e., narrative interview, therapy, writing a diary or a letter, or an authentic conversation with those close to use) favor better understanding of oneself. Thus, a biographic narration, as believed by Wąsiński (2018): "is a necessary condition for self-creation as a process of a personal change defined with an awareness of a distance between the actual me and the real me" (p. 90). A reflection on the past, attention paid to the present, and anticipation of the future help to lend a shape to one's life and repeatedly ask the question about who I am in the world changing around me. In her theoretical study, Pawlak (2009) understands self-creation as being the author of one's own life. The scientist recognizes self-identification, which includes a concept of oneself, a self-assessment, and a metatheory of oneself, goals, and values, as an initial and essential stage of the process of self-creation. The stages to be completed on the way to self-identification include self-cognition, self-explanation, and self-understanding through the creation of self-narration. In conclusion, we understand

7 In the literature, self-understanding and self-cognition are used both as equivalents and as different terms. Here, we use them interchangeably. 
self-creation as a creative process of introducing important life changes (systemic, multi-aspect changes), which depend on the social-historical context, self-cognition, personal aspect, and everyday activity.

At the same time, we consider (cf. Pietrasiński, 2008) unconscious elements of self-creation, e.g. actions taken for professional improvement which are, in fact, the form of an escape from difficult situations. Challenges and realized projects make a reflection on one's own life more difficult and, as a result, are an effect of deceptive self-cognition. Therefore, we notice the unfriendliness of development goals that may favor one's career and may not favor one's loved ones. The approach of Pietrasiński (2008), who has distinguished between intentional and spontaneous self-creation, is quite close to our approach. Intentional self-creation is a conscious and deliberate development and influence on the shape of one's way of life, while spontaneous self-creation consists in unconscious influence on one's own biography through choices made only for temporary pleasures and benefits.

\section{METHODS}

The aim of our study was to reconstruct the decision-making processes in biographies of women who declare that they have made certain important life changes. We identified three research problems: How did the decision-making processes of the interviewees look like? What do the obtained narrations say about individual and social contexts of life changes? What do the life histories we have listened to have in common?

\section{Participants}

The study was conducted from 2016 to 2019. Eleven Polish women and one Turkish woman, ${ }^{8}$ aged 35 to 75 , participated in the study. Nine interviewees live in large Polish cities (i.e., Łódź, Warsaw, Krakow, and Gdansk) and two run agritourism farms in the countryside. The Turkish woman had lived in Poland with her family for two years. One woman is retired; others are still professionally active. Only one of them works under an employment contract; others are freelancers, self-employed, or work under civil law contracts. ${ }^{9}$ Ten narrators have completed higher education. As to their marital status, there were four married women, five women cohabiting with their spouses (including two divorcees), and three women with no spouse; five of them have children aged 14 to 27. We adopted the following criteria of choosing the narrators: 1) age - 30 or above, as (based on development stages of an adult individual) people at that age reach the height of their physical and mental powers, which enables them to become financially independent and to perform their family and professional obligations responsibly; 2) an important life change (in the subjective

\footnotetext{
8 We talked to that narrator in English.

9 See our publications where we provide details on the interviewees' jobs before and after significant life changes (Chmielińska \& Modrzejewska-Świgulska, 2020a, 2020b).
} 
opinion, i.e., a declaration of the women that they have made a significant life change, and in the objective opinion, i.e., indicated by the facts collected concerning the narrators); 3) eight interlocutors were described in an article in a women's journal presenting women who made significant life changes; and 4) the remaining four interlocutors were selected using the snowball method/ nomination; namely, they were recommended to us as individuals who had made a significant life change and they confirmed that nomination (the second selection criterion) (Chmielińska \& Modrzejewska-Świgulska, 2020a, 2020b).

\section{Procedure and Data Collection}

We assumed that to achieve our goal, we should collect stories on lives, which would help us capture the biographical processes (Bertaux, 2012). That is why the attempt to understand life-changing processes required a biographical narrative approach, which concentrates on uniqueness, but also includes historical and social conditions (Gibbs, 2011; Lalak, 2010). We decided to apply two techniques for collecting qualitative data: 1. narrative interview - it was a basic method of collecting data (Kvale, 2010; Wengraf, 2002), and 2. Line of life - it was a supplemented technique (Chmielińska \& Modrzejewska-Świgulska, 2020a, 2020b). The stages of our interviews were as follows (Kaufmann, 2010; Kvale, 2010; Rosenthal, 2012; Urbaniak-Zając \& Kos, 2013):

1. Introduction - we explained the goal of the study and the expected course of the meeting (i.e., an interview and work using the Line of life technique). The narrators were also informed about how the contents of the interviews would be used.

2. Stimulation to tell the story - we read the initial dispositions for the interview (a stimulation to tell the story).

3. Main narration - we listened to our interviewees actively, with no interventions (i.e., requests for more information). If something was unclear and we believed it was worth asking additional questions, we took notes (each of us took our own notes, without any consultation). A clear end of the story communicated by the interviewee, with no intention to add or comment anything at that stage, was the sign that this stage was over.

4. Asking questions - it included two types of questions (i.e., internal ones, referring to what the interviewee said and to the notes taken by us during listening).

5. Final stage (small talk) - here, we changed the topic to something random, not related to the study; we often proposed a break, a moment of relaxation before the second part of the conversation and work with the Line of life.

The second data collecting technique (i.e., Line of life), consisted in marking moments/events recognized by the narrators as crucial/significant/decisive for their biographies on the timeline of the narrators' age. We wanted to collect data free from the interviewees' interpretation (e.g., concerning education, dates, changes of places of residence, changes of job, or professional retraining). The 
Line of life has been created to organize biographical events with reference to time (diachronically) and to put them in collective contexts related to social and historical events.

\section{Data Analysis Strategy}

Work on interpretation consisted in preparing detailed case studies for searching for and comparing shared biographic themes in all collected narrations, which has resulted in, among other things, the identification of three biography types/self-creation methods presented in this paper with an example of a case study (Chmielińska \& Modrzejewska-Świgulska, 2020a, 2020b; Denzin, 1990; Rosenthal, 2012). The interpretation was three-fold, basing on the suggestion of Denzin (1989): (1) analysis of narration on one life story/case interpretation (see example below); (2) collecting group narrations that would be grouped around common biographical threads; (3) comparative analysis of life stories of the studied people. The categories below serve as key words that would saturate the theory of life re-decisions: diachrony (concerns events in the report that were prior and following it; biographical time) and synchrony of life events (simultaneous process taking place during a certain period of time), recurring life processes, frequently recurring mechanisms of life changes, breakthrough events understood as those that would redefine women's biographies, tasks realized throughout life and the life strategies of their realization, criteria of making decisions, life alternatives, and the broader historical of individual biographies (Chmielińska \& Modrzejewska-Świgulska, 2020a, 2020b). ${ }^{10}$

\section{RESULTS}

Cognitive results of qualitative research and the manners of their presentation do not follow the traditional ones that are accepted in social sciences.; namely, there is no representative sample group or statistical relevance. Qualitative research applies alternative methods of generalization basing on the analyzed cases. One of the most commonly applied ways of presenting results is typologization, naturalistic generalization (context-related) and detailed descriptions. Stories told to us by the interviewed women represent three types of biographical self-creations differing from each other by the processes of life changes:

- biographical self-creation, called "spreading one's wings" - changes are incremental and are clearly inscribed into the historical context and all group processes that are part of it. Therefore, changes in the interlocutors' life take place on the continuation basis; evolutionally (goals, plans, life projects, dreams). That biography type is described from the viewpoint of a misfit (i.e., in opposition to the existing world). The women's narrations share the chronological time structure; continuity is the main category that organizes 
biographical experiences. That biography type has been reconstructed based on five obtained life stories.

- decades that may also be seen as stages of psycho-social development. Life changes take place by breaking up and constructing a completely new life project. The women's narrations share the formula of telling the life story as closed chapters; fulfilment is the main category organizing biographic experiences. That biography type has been reconstructed based on six obtained life stories.

- biographical self-creation, called "deus et machina," where changes can be compared to a rapidly terminated "life." Life decisions surprise the women and people closest to them. That biography type has been reconstructed based on one collected life story (Chmielińska \& Modrzejewska-Świgulska, 2020b).

\section{“Spreading One's wings:" Stories about Continuity and Belonging}

The life stories of the "spreading one's wings" type remind one of "The Ugly Duckling" tale by Hans Christian Andersen - they are stories of "misfits" looking for their place and "their" people (Estés, 2001). One of the narrators recalls herself in her student group: When I was completing my studies, almost all my friends had got married and had children. It happened like that with my friends that they married quickly. And certainly, for all of them, the topic of marriage and family was and is important. They wanted to be done with it by the end of university. At that time, that seemed normal, but it was different with me.

Two leading themes may be distinguished in those biography fragments. The first of them is functioning "on the margin;" defining oneself in opposition to members of communities, that is to say primary groups (family, neighbours, peers), the professional group, one's generation, or even the cultural circle. The second one is carrying out long-term life projects, spread over time, and holding together the narrators' biographies. The general biographic question that forms the stories is: Where can I go to "spread my wings;" to activate my development potential (predispositions, dreams, needs) and realize my vision of good life? The protagonists of those self-narrations feel different, not fitting their families (I functioned on the margin of my family), friends (the girls wanted to find a husband and I wanted something else), or times they live in (e.g., the times of communism - ugly, tight, false, mundane). Therefore, to learn about their "originality" they question social messages; they do not want to be only their "carriers;" they make the effort of living according to their own standards, intuitions, and ideas that convince them. It manifests itself in formulating plans and life projects and in attempts to carry them out. One of the interlocutors described her situation as follows: When I worked in a corporation, I met people who travelled, slept in hotels, put their things into suitcases. I didn't like that. My dream to live a true life didn't realize immediately. (...) The women we met were looking for their place and people they could identify with, live according to similar values and beliefs. Just like for the interviewee quoted above, the Himalayas, with their harsh nature, the lifestyle and warmth of their residents, have become a place to which she comes back alone and 
with tourists. We ask questions about the mechanisms of exceeding schematic biographic actions. We form a hypothesis that it is necessary to find a community/people who support one in one's aspirations and in building one's autonomy, which is often related to the need to negate and abandon the current social circles. Therefore, the following processes are important for the "spreading one's wings" biography type: harmonizing me-individual consistent with me-social and developing long-term life projects/development lines/life goal, which often takes place in new places and with new people. Consequences of functioning on the margin of known groups include searching for pro-developmental areas, symbolic (e.g., art, Buddhism, travelling, science, meditation, working with one's body, dance, etc.) as well as literal, geographical ones (e.g., the Himalayas, America, city, countryside, where one may construct one's positive identification, have the feeling of belonging, and activate one's development potential; see Chmielińska \& Modrzejewska-Świgulska, 2020b).

\section{"Milestones:" Stories about Episodes and Transitions}

To refer to established biographical studies by Schütze (2012), "milestones" seem nearest to the biographical metamorphosis considered in the context of significant life changes, manifesting themselves with the initiation of a new development line, taking up new and important activities. To reflect life experienced non-linearly and more episodically, we have used the expression "milestones," which is characterised by:

- dividing life into periods which differ greatly from one another, which are not balanced in terms of aspirations, accomplished goals, performed tasks and life roles, where the development of interests or professional competences may take place in a multifaceted and inconsistent way, in a direction that is hard to predict;

- experiencing a multi-aspect transformation in the professional and private sphere, which we call a transition period and which links the old life with the new life.

What inspired the "milestones" metaphor, was the attribute of Tom Thumb from the story by Charles Perraulta. In our metaphor, we refer to magic properties of the boots, which enabled one to travel far distances with one step, and to find oneself in a completely different place.

In "milestones," the women's stories are organized with the category of changeability. Changes do not take place continually, by carrying out a life plan, transferring competences, aspirations, and dreams, as in the "spreading one's wings" type, but by initiating and developing completely new development lines (I was stuck because of painting, I had to adapt myself to teach completely new classes). As a consequence, the described life periods differ greatly with regard to the goal, performed tasks, or perceiving one's life role or even lifestyle (e.g., new image, diet, job, relationships). The following structures of biographic processes are characteristic of "milestones:"

1. "Incompatible" life periods. The narrators give their lives a structure of life periods that are different from one another. What is important for the dynamics of biographic processes 
is turning points and periods, as the interlocutors call them, of transition, maturation. As a result of a decision, one life sphere accelerates, becomes an area of intensive activity, learning, experimenting, and other areas are seen as the background, the outskirts of life.

2. Moments of "breaking up" as turning points. The narrators experience the feeling of nonsynchronism (i.e., the inconsistency between their needs and the way in which they live), which may be the beginning of the "transition" period (I had enough, the time came to take care of myself. I wanted to break up with everything). In the narrator's opinion, those are the moments that "recall" the current form of their life, as they emphasized themselves, the moments of turning away, breaking up. At the same time, the interlocutors' activity began to focus on new life tasks.

3. Period(s) of transition. It is usually a long period in the narrators' lives in which multi-aspect changes take place in the sphere of values, beliefs, and, as a consequence, in the professional and private sphere. The period of transition is described as maturation, preparation, as the time when everything happens at the same time, simultaneously. Women take up new activities that have not been planned before, in particular in the professional sphere and in the sphere of their interests. They experiment, learn, and abandon the activities they had performed for many years; marginalized elements of their lives become main directions of their activity, which becomes multi-directional. In "milestones," good education, well-paid jobs, or competences achieved for many years are abandoned and replaced with new experiences. The period of transition is experienced with ambivalence as a period of conscious activity preparing one for the change, but also as the time of feeling lost, chaos and loneliness, because the women cannot yet answer the question what they really want and what will happen next. The result of the period of "transition" is a situation that differs significantly from earlier experiences, as the elements creating the vision of oneself and one's world become transformed (Chmielińska \& Modrzejewska-Świgulska, 2020b).

Below, we describe an example of case study where changes are perceived as "milestones". The presented case study is part of our research:

\section{Case study of self-creation: from banking specialist (leader) to yoga teacher}

This part presents a case study involving a woman whose self-creation path ran from being a mother and a housewife, through working as a banking specialist, to becoming a yoga teacher. The described transformation took place in three intervals lasting for 10-17-10 years respectively; as a consequence, we recognize that biographical self-creation as "milestones." Anyway, as the narrator herself states:

I have analysed myself once in the past and I saw that it takes a decade in my life somehow; each ten years, I have a moment in life when something important happens. 
The narrator divides her own biography into three important stages, which we call "milestones," as they change the narrator's current rhythm of life. The narrator starts her story from the stage of early adulthood, related to the formation and the start of family life. What is characteristic of the narration concerning that stage of life is perceiving herself in categories of family beliefs, far from her own needs. That may be illustrated with two decisions. The first one concerning the choice of the university course. The narrator is a biologist by education, but not by her own choice. Her main motivation included her mother's encouragement to study biology as, in her opinion, an interesting discipline and the example of her cousin who had graduated as a biologist earlier. Another topic described at this stage is starting up a family, which also takes place somehow "beside" the narrator. An impression may be made that when telling about motherhood she continues the story of women from her family where, however, she did not manage to be herself, which we can conclude looking back. The decision about getting married and having children is realized automatically and outside of her consciousness, based on the model of life known from the inter-generation experience of women from her family. From the perspective of time, the narrator declares that at that stage she had followed the stereotypical path taken by her mother and grandmother, consisting in raising children and being a good wife and house wife, trusting that what she already knew would be good also for her. What may be noticed first and foremost is the feeling of dissatisfaction, weariness of monotony and repetitiveness, a failure to be herself in her role, and the feeling of no sense in everyday activities. That continued until she reached a turning point where she decided to change everything.

At the second stage, the narrator declares a complete transformation of both the form and contents of her life. She began her next "milestone;" this time, it was related to a job in a corporation. The decision about taking a job in a bank was made by accident; that job simply "fell" in the narrator's lap. It was not a deliberate choice:

And so I started to work in a bank. It was all the same to me who would employ me as I was simply looking for a job. It was not something related to my education, as I am a biologist, but they needed someone who knew English, with higher education, and I met those requirements, so I started to work in the bank's secretariat.

That was the time of immersing herself in something completely different than before, the time of intensive learning, the time of being among people, the time of successes related to promotion and good material situation. Although that experience was different as compared to her life up to that point, she sums up the corporate stage of her life as rearranging papers with no greater sense, and missing the thing that was important to her. That is what she tells about the next turning point:

(...)... and a moment came when that corporation started to take a toll on me, a great toll. . .(...) I became aware that unless / did something with my life, if it went on and on without any change, I would become ill.

What is important is the fact that the narrator did not make the decision to leave the job herself; she decided to wait until she was sacked. And so it happened. After that stage, in the declarations of the narrator, for the first time a reflection on her further career appeared in the form of a readiness to learn about herself and her needs:

(...) the will to search for my own way, to be myself. It seems that something harms us, we feel bad about it but we do not know what to do with that, what to do next. And then I found out that I want to help other people. I have to do something which would be useful for other people.

The third stage, which ends the story and changes its rhythm, is the decision about starting practicing yoga and training to be a yoga teacher. As a result, another "milestone" started, which lasted for 10 years at the time of the interview. Again, the started lifestyle involved immersing in a new experience, abandoning the skills and competences from the previous stage, and starting learning yoga from the very basics, together with socializing in a different environment (trips to India, meeting her masters). What was different in experiencing herself at that stage of her life is making a decision for the first time in a conscious, independent, and well-thought-out manner, based on her own needs. It is the stage where the narrator declares, for the first time, that she has the feeling of being rooted and of her decisions being meaningful.

Each of the described decades of life involves development in a different role and a different context (the family life - in the role of a mother and a housewife in the home space; the banking career - in the role of a leader in a big corporation; the career of a yogi - in the role of a teacher in the changing geographic space Łódź- India). In each of those threads, the narrator told us about a completely different type of experience:

- The first stage: experiences of relationships and care; 
- The second stage: intellectual experiences related with improvement of professional competences and management of people;

- The third stage: experiences related with her body and the spiritual sphere of life.

In that narrator, various directions of self-creation may also be distinguished: from others to herself, from dependence to independence, from no awareness of her own needs to autonomy in making decisions, from remaining in the sphere of intellect to spirituality, from being in the same place to changing the environment and the context of learning in a different culture.

Among women's narrations about the experience of self-creation, that one seems important to us as it shows a different dimension of self-creation; one that is described in research and literature less frequently. The described way of self-creation is not linear and continuous. It does not include gradual improvement of competences and development of life projects started at the earlier stages of life. More and more research, including ours, indicates that people, in their development, take multidirectional actions, choose diverse and inconsistent aspirations, change or even abandon themselves, their talents, and interests rather than get to know them in more detail (Giddens, 2007; 0leś, 2019). In the course of self-creation, people completely change their framework of reference in which they had lived their lives so far. They start to feel ready; they find the courage to use other categories of thinking about themselves and to introduce new categories of describing themselves in the assumptions made beforehand, such as the calling, one's own way, mission, and the feeling of sense and meaning.

And thus, in a similar way, the selected narration illustrates a kind of discontinuation, inconsistency, no integration of aspirations in different areas. Subsequent life and professional choices of the narrator do not realize complementary goals; on the contrary, from the perspective of time, we may say that the woman opposes those goals, describes the feeling of no satisfaction that accompanied her at the time, the feeling of internal pressure to stop something and making a fresh start. Each subsequent stage, apart from the last one, ends with a great level of frustration as a consequence of no consent to be herself and leading an unsatisfactory life. It is only the third decade of her life that involves, as declared by the narrator, finding her own way of life, as she calls it. Her narration includes categories of feeling fulfilled, being herself, and finding her own place.

The path of self-creation is also demonstrated through the gradual escape from the pressure of the environment and the need to follow her own original project of life. It is the intuitive following of a constantly present yearning for doing something, which the author would recognize as meaningful. The optimistic message, which may be read when analyzing this case, is the fact that it is an example of life where, paradoxically, no fulfilment brings an individual closer to the stage of life where they finally start to experience themselves as a person they had wanted to be for a long time.

Source: Authors' research

\section{"Deus ex machina:" A Story about What Happens When You "Fly to the Moon"}

The third type was created based on a single story and episodes from other life stories obtained during the study. It is not a large empirical material and, undoubtedly, it requires further research; however, it seems so interesting and heuristic to us that we have decided to present it as a kind of a "naturalistic generalization." We have followed the suggestion of Stake (2009), who believes that a single case may become a starting point for more general conclusions. The story was told by a woman who had experienced many years of work in a corporation. In practice, she had become trained as a journalist and performed high-level management functions in a publishing company. At the age of 35 , she decided to leave her job and went on her first (but not last) long and far journey alone. At present, she is an author of four travelling books. To describe that story, we use the "deus ex machina" metaphor, as the life change experienced by the narrator was called surprising, sudden, and difficult to explain in the context of the course and logics of her current life. The "deus ex machina" solution was used by 
Euripides. He introduced, to his dramas, a god who was supposed to end the action by his appearance so that the play does not last for too long and bore the audience.

The interlocutor focused on the professional sphere; she told us about her decision to leave her job and start a journey that had not been planned before. That decision divides the interlocutor's life into two stages: "before" and "after" the re-decision, which is an important characteristic of epiphanic experiences. In the case of creative skills, epiphanic/borderline or crystallizing experiences (Gibbs, 2011; Walters \& Gardner, 1986) are key biographical moments as they are "significant/ turning points/decisive moments" (Szmidt, 2017, p. 177); events transforming the current life, beliefs, interests, the manner of perceiving oneself and the world. Experiences of that type are usually mentioned in the context of biographies of eminent scientists, artists, political activists or saints (i.e., individuals who show signs of being unusual; see Kafar, 2011; Szmidt, 2017; Walters \& Gardner, 1986), and more rarely in the context of life histories of ordinary people. In the interlocutor's story, we find the following signs of an epiphanic experience (Denzin, 1989; Kafar, 2011; Miller \& Baca, 2001; Szmidt, 2017):

1. Sudden decision. The narrator emphasizes: One day, when I was falling asleep, like in an American movie, I thought that if I didn't go away now, I would regret that.

2. "Magic" and mysterious experience. The changes happen as if by magic, as if outside the narrator's sphere of decision. The interlocutor said: I can't say when it happened that I wanted to travel; I have never dreamt about travelling.

3. Professional crisis. Before making the "deus ex machina" decision, the narrator experienced a crisis. This is how she recalls the atmosphere at work: I was fed up with my work. After some time, I've had enough of it for various reasons.

4. Life "before" and "after" the decision. In her story, the narrator divides her life into "before" and "after" the decision. "Before" the decision, the job in a corporation was her whole life; it meant many hours at work every day, unused annual leave, no weekends, friends mainly among employees at the corporation. "After" the decision, on the other hand, her life became slower, minimalistic.

5. Permanent and creative change. After the first journey, the narrator had not returned to her earlier lifestyle. She used her journalist skills in a creative way as she wrote four books that sold well.

"Deus ex machina" changes are revolutionary rather than evolutionary as in "spreading one's wings;" they are not preceded with the transition period and preparation to one's new life as in "milestones" either. We suppose that, in spite of all, such changes are possible based on financial resources that one already has and that support the revolutionary life decisions, as women who make such decisions had well-paid jobs for many years, savings, as well as human resources (i.e., they had the mental support of their family and friends). In addition, they do not have any family 
responsibilities and children; they are unmarried and have informal relationships (Chmielińska \& Modrzejewska-Świguska, 2020b).

\section{DISSCUSION}

The purpose of this paper was to present three biography types (which we also describe as a manner of self-creation of one's life, i.e.: spreading one's wings, milestones, and deus ex machina). The proposed biography types have been identified based on reconstructions of life stories of women who declared that significant life changes had taken place in their lives. We aimed at theoretical generalization rather than qualitative one; therefore, we have created the types based on similar cases (Rosenthal, 2012). All life stories were set in the background of the process of global social changes: economy of Polish People's Republic (PRL) ${ }^{11}$ of the Edward Gierek decade, system transformations by the end of the 80s and year 1989 as a breakthrough, the economic crisis of 20082013 (including restrictions of loans imposed by banks and decreasing the currency value), change in the ruling parties PO/PiS, and the latest history of Poland. The stories of personal changes have become, indirectly, stories about social and historical changes. Reconstruction of individual life stories and embedding them in a specific time in history makes one aware of the importance of global processes for the course of an individual way in one's life, as the social and historical context is related to different life possibilities. Such parallelism seems quite obvious: an individual born in the 1950s has experienced the economic crisis of 2008-2013 severely; likely, at that time they had an established career and the crisis could have been an important factor that caused dynamic changes in their professional life.

When making biographical reconstructions of individual cases, it is not sufficient, however, to refer to the historical context or to point to processes of social changes. In qualitative biographical studies, it is important to search for relationships between collective processes, individual ways in life, and their family context. We assume that the narrations about the introduction of life changes make it easier to construct "parallel" stories (i.e.: embed one's own life story in a global/historical time). The historical background described in the narrations we analyzed had more of a generative/creative function than a reconstructive/factographic one. We form a hypothesis that stories about change may be "doubly creative", meaning they generate creatively told life stories about self-creation processes and one's own subjectivity. To go even further, we ask a question: do stories about life changes favor recollection and interpretation of the historical context of one's life? Here, it is worth to refer to studies on autobiographical memory. It contains memories of personal and general events and is constructed of cognitive patterns, which are generalized or abstract and not just factographic (przypis). The generative operation of the autobiographical memory favors cognitive openness and ensures adaptive flexibility (Maruszewski, 2005), which may be important 
during the creation of long-term life plans and changes. The hypothesis concerning biographical time and historical time in narrations about life changes and self-creation requires the use of methods typical for studies on autobiographical memory and considerations at the borderline between creative psychology and narrative psychology. It would be interesting to conduct a study including a larger sample of women representing various generations to confirm our research hypotheses. The processes of life changes are also concurrently conditioned by individual biographical factors, such as generation or family experience. The collected stories reflect the universal, local and individual dimension of a biography.

Biography types differ in descriptions of actions taken and the manner of presenting the protagonist of the narration. In "spreading one's wings" biographies, the narrators create an image of women taking actions that are supposed to bring them nearer to their dreams as well as educational, professional, and relational goals, even if such life plans have been abandoned at some time in the past. Searching for a place that would make it possible for one to accomplish their dreams and realize their plans has become an important motif of "spreading one's wings." The character of the protagonists decided about the actions they took; therefore, those were "psychological stories" told in a linear way. On the other hand, protagonists of "milestones" described their life divided into episodes; subsequent stages of their lives differed greatly from one another with regard to the life roles the women played. That biography type includes crises triggering a long "transition period" after which life takes a completely new direction. The protagonists of "deus ex machina," on the other hand, make radical and sudden decisions on a change, which is surprising to themselves as well as to the people closest to them. We assume that this very biography type may be recognized in women from the young generation who are well-educated, who earn well, and who courageously break up with social expectations and patterns. Our studies show that as a result of life changes the women were longer been afraid of being different from others. They have come to believe that their needs themselves are not wrong, dishonest, unprofessional, or unjust to people around them. They started to describe their own needs, goals, standards, and values with no reference to the outside; they re-directed their search to the inside. Therefore, our studies are part of a reflection in humanist psychology, where mental health is described, among other things, as striving to obtain autonomy and independence from one's environment.

To sum up, the notion of self-creation should be linked to the whole-life processes of forming one's own biography. Self-creation is positive and is not an escape from difficult situations by taking up new challenges or projects, which in fact lead one further from the reflection on one's own life. However, our study is not free from limitations. Qualitative studies are burdened with the error of subjectivism (the interpretation is insufficiently established in qualitative studies) and unjustified generalizations. The topic of life changes itself could have, indirectly, forced the narrators to feel the need to generate stories originating from people who actually made important and original life changes and, as a consequence, could have imposed self-presentation topics matching themes present in mass media, for example. Despite the limitations of qualitative studies, the analyses have led us to identify three biography types and the re-decision model (a cycle of a change of the self- 
realization manner), which seem a promising direction of studies on processes of life changes in adult life. At present, work is in progress on a questionnaire concerning life re-decisions.

\section{References}

Arons, M. (2007). Standing up for Humanity: Upright Body. Creative Instability, and Spiritual Balance. In R. Richards (Ed.), Everyday creativity and new views of human nature. Psychological, social, and spiritual perspectives (pp. 175-193). Washington DC: American Psychological Association.

Bertaux, D. (2012). Analiza pojedynczych przypadków (au cas par cas) [Study case analysis]. In K. Kaźmierska (Ed.), Metoda biograficzna w socjologii [The biogarfical method in sociology] (pp. 309-333). Kraków: Zakład Wydawniczy NOMOS.

Bauman, Z. (2009). Konsumowanie życia [Consuming Life]. Kraków: Wydawnictwo Uniwersytetu Jagiellońskiego.

Całek, A. (2019). Nowa teoria listu [New Letter Theory]. Kraków: Biblioteka Jagiellońska i Księgarnia Akademicka.

Chmielińska, A. (2017). Dynamika transgresji twórczych. Studia przypadków pedagogów [Dynamics of creative transgressions. Case studies of educators]. Łódź: Wydawnictwo Uniwersytetu Łódzkiego.

Chmielińska, A., \& Modrzejewska-Świgulska, M. (2020a). Women's life (re)decisions. Report from biographical narratives. Przegląd Badań edukacyjnych, 30(1), 87-105.

Chmielińska, A., \& Modrzejewska-Świgulska, M. (2020b). W stronę samorealizacji. Re-decyzje życiowe kobiet [Towards Self Realization. Women's life re-decisions]. Łódź: Wydawnictwo Uniwersytetu Łódzkiego.

Craft, A. (2000). Creativity across the primary curriculum. London-New York: Continuum.

Craft, A. (2001). Little c creativity. In A. Craft, B. Jeffrey, \& M. Leibling (Eds.), Creativity in education (pp. 45-61). London-New York: Continuum.

Craft, A. (2002). Creativity and early years education. London-New York: Continuum.

Davis, G.A. (2004). Creativity is forever. Dubuque-lowa: Kendall/Hunt Publishing Company.

Denzin, N.K. (1989). Interpretative Biography. Newbury Park: Sage Publications.

Dubas, E. (2017). Uczenie się z własnej biografii jako egzemplifikacja biograficznego uczenia się [Learning from your own biography as an exemplification of biographical learning]. Nauki o Wychowaniu. Studia Interdyscyplinarne, 4(1), 63-87.

Elisondo R.C., \& Vargas A. (2019). Women's Everyday Creative Activities: a Qualitative Study. Creativity. Theories - Research-Applications, 6(1), 91-111.

Estés, C.P. (2001). Biegnaca z wilkami. Archetyp Dzikiej Kobiety w mitach i legendach [Women Who Run With the Wolves. Myths and Stories of the Wild Woman Archetype]. Poznań: Wydawnictwo Zyski S-ka.

Fukuyama, F. (2000). Koniec historii [The end of history]. Poznań: Wydawnictwo Zysk i K-ka.

Gibbs, G. (2011). Analizowanie danych jakościowych [Analizing Qualitative Data]. Warszawa: Wydawnictwo Naukowe PWN.

Giddens, A.(2007). Nowoczesność i tożsamość [Modernity and Self-Identity. Self and Society in the Late Modern Age]. Warszawa: Wydawnictwo Naukowe PWN.

Jacyna, M. (2007). Kultura indywidualizmu [The culture of individualism]. Warszawa: Wydawnictwo Naukowe PWN.

Kafar M. (2011). Biograficzne epifanie w kontekście tworzenia podstaw jakościowego kolektywu myślowego [Biographical epiphanies in the context of creating a qualitative research collective]. In. M. Kafar (Ed.), Biografie naukowe. Perspektywa transdyscyplinarna [Scientific biographies. A transdisciplinary perspective] (pp. 37-66). Łódź: Wydawnictwo Uniwersytetu Łódzkiego,

Kaufman, J.C. (2010). Wywiad rozumiejący [Undertanding interview]. Warszawa: Oficyna Naukowa. 
Kubiak, A.E. (2005). Jednak New Age [However New Age]. Warszawa: Jacek Santorski \& Co Agencja Wydawnicza Sp. z o.o.

Kvale, S. (2010). Prowadzenie wywiadów [Doing Interviews]. Warszawa: Wydawnictwo Naukowe PWN.

Lalak, D. (2010). Życie jako biografia. Podejście biograficzne w perspektywie pedagogicznej [Life as a biography. A biographical approach in a educational studies]. Warszawa: Wydawnictwo Akademickie Żak.

Maruszewski, T. (2005). Pamięć autobiograficzna [Autobiographical memory]. Sopot: Gdańskie Wydawnictwo Psychologiczne.

Miller, W.C., \& Baca, C.J. (2001). Quantum Change: When Epiphanies and Sudden Insights Transform Ordinary Lives. New York: The Guilford Press.

Modrzejewska-Świgulska, M. (2014). Twórczość codzienna w narracjach pedagogów [Everyday creativity in educator's narrations]. Łódź: Wydawnictwo Uniwersytetu Łódzkiego.

Oleś, P.K. (2019). The Paul Gauguin Syndrome: A Great Life Change. In I. Lebuda, \& V.P. Glăveanu (Eds.). The Palgrave Handbook of Social Creativity Research (pp. 317-334). Cham: Palgrave Macmillan.

Pawlak, J. (2009). Autokreacja. Psychologiczna analiza zjawiska i jego znaczenie dla rozwoju [Self-creation. Psychological analysis of the phenomenon and its importance for development]. Kraków: Wydawnictwo WAM.

Pachucki, M.A., Lena, J., \& Tepper, S. (2010). Creativity Narratives among college students: sociability and everyday creativity. The Sociological Quarterly, 51, 122-149.

Pietrasiński, Z. (2008). Ekspansja pięknych umysłów. Nowy Renesans i ożywcza autokreacja [Expansion of beautiful minds. New Renaissance and invigorating self-creation]. Warszawa: Wydawnictwo CIS.

Richards, R. (1990). Everyday creativity, eminent creativity, and health. Creativity Research Journal, 3, 300326.

Richards, R. (1997). Conclusions: When illness yields creativity. In M. A. Runco, \& R. Richards (Eds.), Eminent creativity, everyday creativity and health (pp. 487-540). London: Ablex Publishing Co.

Richards, R. (2007). Everyday creativity: Our hidden potential. In R. Richards (Ed.), Everyday creativity and new views of human nature. Psychological, social, and spiritual perspectives (pp. 25-53). Washington DC: American Psychological Association.

Richards, R. (2010). Everyday creativity: Process and Way of Life - Four Key Issues. In J.C. Kaufman, \& R.J. Sternberg (Eds.), The cambridge handbook of creativity (pp. 189-215), Cambridge: Cambridge Univeristy Press.

Richards, R., \& Kinney, D. (1997). Mood swings and creativity. In R. Richards, \& M.A. Runco (Eds.), Eminent creativity, everyday creativity and health (pp. 137-156 ). London: Ablex Publishing Co.

Richards, R., \& Kinney, D.K., \& Lunde, I., \& Benet, M., \& Merzel A.P.C. (1997). Creativity in manic-depressives, cyclothymes, their normal relatives, and control subjects. In M.A. Runco, \& R. Richards (Eds.), Eminent creativity, everyday creativity and health (pp. 118-136). London: Ablex Publishing Co.

Rosenthal, G. (2012). Badania biograficzne [Biographical research]. In K. Kaźmierska (Ed.), Metoda biograficzna w socjologii [The biogarfical method in sociology] (pp. 309-333). Kraków: Zakład Wydawniczy NOMOS.

Runco, M.A. (1996). Personal creativity: Definition and developmental issues. New Directions for Child Development, 72, 3-30.

Runco, M. A. (2006). Reasoning and personal creativity. In J.C. Kaufman, \& J. Bear (Eds.), Creativity and reason in cognitive development (pp. 99-116). Cambridge: Cambridge University Press.

Runco, M.A. (2007). To understand is to create: An epistemological perspective on human nature and personal creativity. In R. Richards (Ed.), Everyday creativity and new views of human nature. Psychological, social, and spiritual perspectives (pp. 91-107). Washington DC: American Psychological Association.

Sawyer, K. (2006). Explaining creativity. The science of human innovation. New York: Oxford University Press.

Schulz, R. (1990). Twórczość - społeczne aspekty zjawiska [Creativity - social aspects of the phenomenon]. Warszawa: Wydawnictwo Naukowe PWN. 
Schütz, A. (2012). Analiza biograficzna ugruntowana empirycznie w autobiograficznym wywiadzie narracyjnym. Jak analizować autobiograficzne wywiady narracyjne [Biographical analysis grounded empirically in an autobiographical narrative interview. How to analyze autobiographical narrative interviews]. In K. Kaźmierska (Ed.), Metoda biograficzna w socjologii [The biogarfical method in sociology] (pp. 141-278). Kraków: Zakład Wydawniczy NOMOS.

Sennett, R. (2010). Kultura nowego kapitalizmu [The culture of new capitalism]. Warszawa: Spectrum.

Stake, R.E. (2009). Jakościowe studium przypadku [Qualitative case study]. In N.K. Denzin, \& Y.S. Lincoln (Eds.), Metody badań jakościowych [The Sage Handbook of Qualitative Research] (vol 1, pp. 623-654). Warszawa: Wydawnictwo Naukowe PWN.

Szmidt, K.J. (2013). Pedagogika twórczości [Pedagogy of Creativity]. Sopot: Gdańskie Wydawnictwo Psychologiczne.

Szmidt, K.J. (2017). Edukacyjne uwarunkowania rozwoju kreatywności [Educational conditions for the development of creativity]. Łódź: Wydawnictwo Uniwersytetu Łódzkiego.

Sztompka, P. (2010). Socjologia zmian społecznych [Sociology of social changes]. Kraków: Wydawnictwo Znak.

Swann, J., \& Maybin, J. (2007). Introduction: Language creativity in Everyday. Applied Linguistics, 28, 497517.

Tan, A.G., \& Lai-Chong, L. (2004). Creativity for teachers. Singapore: Marschall Cavendish Academic.

Torrance, E.P. (1995). Why fly? A philosophy of creativity. Norwood, NJ: Ablex Publishing Corp.

Urbaniak-Zając D., \& Kos E. (2013). Badania jakościowe w pedagogice [Qualitative research in pedagogy]. Warszawa: Wydawnictwo Naukowe PWN.

Uszyńska-Jarmoc, J. (2007). Od twórczości potencjalnej do autokreacji w szkole [From potential creativity to selfcreation at school]. Białystok: Trans Humana.

Wąsiński, A. (2018). Autokreacje małżonków bezdzietnych do wielowymiarowego rodzicielstwa adopcyjnego [Self-creations of childless spouses for multidimensional adoption parenting]. Łódź: Wydawnictwo Uniwersytetu Łódzkiego.

Walters, J., \& Gardner, H. (1986). The Crystallizing Experience: Discovering a Intellectual Gift. In R.J. Sternberg, \& J. Davidson (Eds.), Conceptions of Giftedness (pp. 306-330). New York: Cambridge University Press.

Wengraf, T. (2002). Qualitative Research Interviewing. California-New Delhi: Sage.

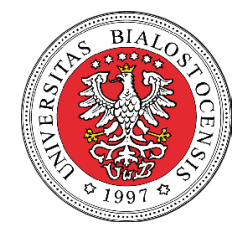

(c) Copyright by Faculty of Education, University of Bialystok,

20 Swierkowa St., 15-328 Bialystok, Poland

tel. +48857457283

e-mail: creativity@uwb.edu.pl

http://www.creativity.uwb.edu.pl 